\title{
Differential Gene Expression and Regulation of Angiotensin II Receptor Subtypes in Rat Cardiac Fibroblasts and Cardiomyocytes in Culture
}

Hiroaki Matsubara, Mikihiko Kanasaki, Satoshi Murasawa, Yasuyuki Tsukaguchi, Yutaka Nio, and Mitsuo Inada Second Department of Internal Medicine, Kansai Medical University, Fumizonocho 1, Moriguchi, Osaka 570, Japan

\begin{abstract}
Although both rat cardiac nonmyocytes (mostly fibroblasts) and cardiomyocytes have a functional angiotensin II (AngII) receptor, the regulation mechanism of its subtype expression in the rat heart remains unknown. In this study, by using a binding assay and a competitive reverse-transcriptase polymerase chain reaction, we examined the regulation of AngII types 1a and $1 \mathrm{~b}$ (AT1a-R and AT1b-R) and type 2 receptor (AT2-R) expression in embryonal day 19 (E19) and neonatal (1-d) rat cardiac fibroblasts and cardiomyocytes. The number of AT2-R in E19 fibroblasts was dramatically decreased (from 305 to 41 fmol/mg protein) in 1-d fibroblasts, whereas that of AT1-R and the mRNA levels remained unchanged. The ratio of AT1a$R$ to AT1b-R mRNA in both E19 and 1-d fibroblasts was 9:1. The number of AT2-R in E19 cardiomyocytes was also significantly decreased (from 178 to $87 \mathrm{fmol} / \mathrm{mg}$ protein) in 1-d cardiomyocytes, whereas the magnitude was less prominent compared with that in fibroblasts. AT1-R expression remained unaltered in E19 and 1-d cardiomyocytes. In E19 and 1-d cardiomyocytes, the AT1b-R mRNA level was 1.5-fold higher than that of AT1a-R mRNA. Dexamethasone induced significant increases in AT1a-R mRNA (2.1-fold) and numbers (1.8fold) without changing the affinity, whereas neither AT1b-R mRNA nor the number of AT2-R was affected by dexamethasone. The AT1a-R gene transcription rate, determined by means of a nuclear run-off assay, was increased (2-fold) by dexamethasone. The half-life of AT1a-R mRNA (18 h) was unchanged by dexamethasone. These data indicate that AngII receptor subtype expression in the rat heart is regulated in a cell- and subtype-specific manner. (J. Clin. Invest. 1994. 93:1592-1601.) Key words: angiotensin II receptor • cardiac fibroblast • cardiomyocyte • gene expression • polymerase chain reaction
\end{abstract}

\section{Introduction}

Angiotensin II (AngII) ${ }^{1}$ has multiple physiological effects directly and indirectly on the cardiovascular system that are initi-

Address correspondence to Dr. Hiroaki Matsubara, Second Department of Internal Medicine, Kansai Medical University, Fumizonocho 1, Moriguchi, Osaka 570, Japan.

Received for publication 23 September 1993 and in revised form 24 November 1993.

1. Abbreviations used in this paper: $\mathrm{ACE}$, angiotensin-converting enzyme; ANF, atrial natriuretic factor; AngII, angiotensin II; AT1-R, AngII type 1 receptor; AT2-R, AngII type 2 receptor.

\section{J. Clin. Invest.}

(c) The American Society for Clinical Investigation, Inc.

$0021-9738 / 94 / 04 / 1592 / 10 \$ 2.00$

Volume 93, April 1994, 1592-1601 ated by binding to specific receptors located on the plasma membrane (1). Recently, two benzylimidazole derivatives have been used to distinguish AngII receptor subtypes in several tissues. Dup 753 and TCV-116 inhibits the AngII type 1 receptor (AT1-R), which is the predominant subtype in the adrenal cortex, vasculature, kidney, and liver, whereas PD123319 and CGP42112A inhibit the AngII type 2 receptor (AT2-R), present in the adrenal medulla, uterus, a subset of brain nuclei, and ovary of the adult animal (for review see reference 2). Both AT1-R and AT2-R subtypes are equally distributed over the myocardium $(3,4)$. The cloning of rat (5-7), bovine (8), human (9-11), and mouse (12) AT1-R cDNA has made it possible to study the AT 1-R gene expression mechanism in the heart at the molecular level. The AT1-R cDNA cloned from bovine adrenal cells $(8)$ and rat vascular smooth muscle cells (5) was termed AT1a-R. The second form of AT1-R (AT1b-R), which exhibited highly homologous sequences and similar binding and functional characteristics, was cloned from the rat pituitary (12) and adrenal glands (7). These subtypes are widely expressed in various rat tissues and the differential tissue-specific regulation of the mRNAs was reported $(7,13)$.

AngII directly stimulates heart rate, cardiac contractility, and growth (14). Subnanomolar concentrations of AngII facilitates adrenergic neurotransmission in the heart (15), indirectly leading to an increase in the heart rate, contractility, and a decrease in coronary flow $(15,16)$. The majority of the cardiovascular and hormone modulating actions of AngII in the adult animal are mediated through the AT1-R (2). Grady et al. (17) have reported that the AT2-R is highly expressed in the mesenchymal tissue of the developing rat fetus and rapidly disappears after birth. Similarly, it has been shown that during embryonic and immediate postnatal development rat aortic smooth muscle cells express AT2-R almost exclusively (18). These findings indicate an AT2-R mediating effect of AngII in tissue growth and development during the embryonic period. In the rat heart, we (3) and others (4) have demonstrated that AngII receptor expression is increased during the neonatal period and decreases with maturation, that the expression of AT 1-R and AT2-R is nearly equal in the rat myocardium, and that the proportion is unchanged through development. However, a number of cell types are present in the heart, in which cardiomyocytes and cardiac fibroblasts are the predominant cell types in the neonatal rat heart (19). Cultured cardiomyocytes as well as cardiac fibroblasts prepared from the neonatal rat heart are immunoreactive to AngII, AngI, and angiotensinconverting enzyme (ACE) (20). Although previous studies have reported the presence of high-affinity AngII binding sites in cardiac tissues $(3,21)$, which cardiac cell types are responsible for the binding sites has not been determined. Schorb et al. (22) have shown that neonatal rat cardiac fibroblasts express a substantial amount of AT1-R rather than AT2-R. In addition, recent studies have also reported that isolated adult rat cardiomyocytes exclusively exhibit the AT1-R subtype (23) and that 
AT1-R mediates AngII-induced hypertrophy of cardiomyocytes (24). Thus, the subtype expression profiles in isolated heart cells appears distinct from those in cardiac tissue. We therefore examined the cell-type specific developmental regulation in AT1-R (AT1a and AT1b) and AT2-R expression using cultured rat cardiomyocytes and cardiac fibroblasts. The result demonstrated that AT1-R and AT2-R expression is differentially regulated during perinatal development in a cell typespecific manner.

It has been reported that AngII receptor levels in the anterior pituitary gland are strongly inhibited by estrogens (25). Kakar et al. (13) have demonstrated that AT1b-R mRNA levels, but not those of AT 1a-R, are suppressed by estrogen in the pituitary gland. Kambayashi et al. (25) have shown that the expression of AT2-R is downregulated in cultured smooth muscle cells by growth factors, in contrast to that of AT1-R, which was slightly upregulated. These findings suggest that AngII receptor mRNA regulation is not in the static state. Glucocorticoids are involved in the regulation of blood pressure (27), in which enhancement of vascular responsiveness has been considered one of the major contributing factors (28). We examined the effect of dexamethasone on the AT1-R mRNAs (AT1a-R and AT1b-R) and AT2-R regulation. The results demonstrated that the ATla-R gene responds to dexamethasone at the transcriptional level, whereas ATlb-R and AT2-R were not affected by dexamethasone.

\section{Methods}

Cell cultures. Enriched cultures of cardiomyocytes and cardiac nonmyocytes were prepared from hearts of embryonal day 19 (E19) and neonatal (day 1 or 7) Wistar rats. All steps were basically performed according to the method published by Dostal et al. (20). The rats were decapitated, and the hearts were removed and placed in HBSS. For each dispersion, hearts from $\sim 250$ rats were minced and digested with $5 \%$ pancreatin ( $\mathrm{vol} / \mathrm{vol}$ ) and $0.32 \mathrm{mg} / \mathrm{ml}$ collagenase II in HBSS with $12.5 \mathrm{mM}$ Hepes. The supernatant from the first step of the digestion procedure ( $10 \mathrm{~min}$ ) containing cell debris and red blood cells was discarded. Cells from the eight subsequent digestions ( $20 \mathrm{~min}$ each ) were collected in 50-ml sterile polypropylene tubes containing 20 $\mathrm{ml}$ of Dulbecco's modified essential medium (DMEM) with $20 \%$ FCS and sedimented by centrifugation at $200 \mathrm{~g}$ for $4 \mathrm{~min}$. The cell pellets, which consisted primarily of cardiomyocytes and cardiac nonmyocytes, were resuspended in $60 \mathrm{ml}$ of DMEM with $20 \%$ FCS. The cell suspensions were combined and incubated for $90 \mathrm{~min}$ at $37^{\circ} \mathrm{C}$ in 25 $\mathrm{cm}^{2}$ flasks, which allowed for selective attachment of nonmyocytes. Since most of nonmyocyte-enriched cultures consist of fibroblasts (19, $20,22,24)$, the cultures are hereafter referred to as fibroblast cultures. Cardiomyocyte-enriched suspensions were removed from the culture dishes and replaced with DMEM containing 10\% FCS. The culture dishes containing attached fibroblasts were placed into an incubator and passaged $48 \mathrm{~h}$ later with $0.25 \%$ trypsin. The fibroblasts were plated in DMEM containing $10 \%$ FCS at a density of $3-5 \times 10^{3}$ cells $/ \mathrm{cm}^{2}$ on $100-\mathrm{mm}$ dish and $35-\mathrm{mm}$ dish or in six-well plastic cell culture dishes containing 22-mm round glass coverslips. After $8 \mathrm{~d}$, the medium was changed to serum-free DMEM and all experiments were performed $1 \mathrm{~d}$ later. To examine its effects, dexamethasone $(1 \mu \mathrm{M})$ was added to DMEM containing 5\% FCS for the indicated period.

Cardiomyocytes obtained from the above differential plating procedure were counted and plated in DMEM containing $10 \%$ FCS and 100 $\mu \mathrm{M}$ of the DNA synthesis inhibitor, bromodeoxyuridine. The cardiomyocytes were seeded at densities of $5 \times 10^{6}$ cells/ 100 -mm dish, 2 $\times 10^{6}$ cells $/ 35-\mathrm{mm}$ dish, and $1 \times 10^{6}$ cells/well into six-well plastic cell culture dishes containing $22-\mathrm{mm}$ coverslips. $2 \mathrm{~d}$ after plating, the culture medium was replaced with serum-free DMEM containing bromo- deoxyuridine $(100 \mu \mathrm{M})$ and the experiments were performed $1 \mathrm{~d}$ later. All media were supplemented with penicillin and streptomycin, and the cells were maintained at $37^{\circ} \mathrm{C}$ and $5 \% \mathrm{CO}_{2}-95 \%$ air. The incubation medium was exchanged every $3 \mathrm{~d}$.

AngII-binding assay for cardiac fibroblasts and cardiomyocytes. The AngII-binding assay for cardiac fibroblasts and cardiomyocytes was based upon the method reported by Schorb et al. (22) and Rogers et al. (29), respectively. Cells on $35-\mathrm{mm}$ dishes were washed three times with $1 \mathrm{ml}$ of incubation buffer, which contained (mM) Tris 50 (pH 7.5), $\mathrm{NaCl} 120, \mathrm{KCl} 4, \mathrm{CaCl}_{2} 1, \mathrm{MgCl}_{2} 1$, and glucose 11, with 0.01 $\mathrm{mg} / \mathrm{ml}$ bacitracin and $0.25 \%$ crystalline BSA. Incubation buffer containing $0.05 \mathrm{nM}^{125} \mathrm{I}$-AngII (New England Nuclear, Boston, MA) for cardiac fibroblasts or $0.05 \mathrm{nM}^{125} \mathrm{I}_{-S^{2}}{ }^{1} \mathrm{Ile}^{8}$-AngII (New England Nuclear) for cardiomyocytes, and increasing concentrations of unlabeled ligands was added to each dish. Incubation proceeded at $23^{\circ} \mathrm{C}$ for 60 min and was terminated by aspirating the binding buffer and washing the cells three times with ice-cold binding buffer. Bound radioactivity was removed by adding $1.0 \mathrm{ml}$ of $0.25 \mathrm{M} \mathrm{NaOH}-0.5 \%$ SDS for $10 \mathrm{~min}$ and washing with an additional $0.5 \mathrm{ml} \mathrm{NaOH}-\mathrm{SDS}$. Radioactivity was measured using a gamma counter (LKB Produkter, Bromma, Sweden ). Counts were corrected for background radioactivity, and the specific binding was determined by subtracting the radioactivity bound in the presence of $1 \mu \mathrm{M}$ of unlabeled AngII. In a typical binding experiments, when cardiac fibroblasts ( $260 \mu \mathrm{g}$ of protein per well) or cardiomyocytes $(220 \mu \mathrm{g}$ of protein per well) were incubated with $0.05 \mathrm{nM}$ ${ }^{125}$ I-ligands, the total binding was 7,246 and $4,948 \mathrm{cpm}$, and the nonspecific binding was 828 and $615 \mathrm{cpm}$, respectively. Receptor density ( $B_{\max }$ value) and $K_{\mathrm{d}}$ values were calculated from Scatchard plots (3). When the binding was normalized to the protein concentration, an aliquot of the SDS extracts was removed and analyzed by the Bio-Rad Laboratories (Richmond, CA) assay using BSA as a standard (3).

Quantitative reverse transcription (RT) and PCR assay. Firststrand cDNA was synthesized from total RNA, as reported for AT la-R mRNA in rat ventricles (3). Total RNA was isolated by means of guanidium isothiocyanate-cesium chloride centrifugation followed by digestion with DNase (Takara Shuzo, Kyoto, Japan) to remove contaminating genomic DNA. The following PCR oligonucleotide primers $(0.5 \mu \mathrm{M})$ were designed from the cDNA sequences common to AT la-R (5) and ATlb-R (7): sense from the 5' coding region (5'-GGAAACAGCTTGGTGGTG- $3^{\prime}$ ) and antisense from the coding region (5'-GCACAATCGCCATAATTATCC-3'). These primers corresponded to the regions where no sequence divergence was noted between ATla-R and ATlb-R. To obtain deletion mutated cRNA $(\triangle \mathrm{AT} 1-\mathrm{R})$, the 607-bp PCR product was treated with T4 polynucleotide kinase ( Takara Shuzo) and blunt-ended with Klenow DNA polymerase (Takara Shuzo) for subcloning into the EcoRV site of pBluescript II KS(-) (Stratagene Inc., La Jolla, CA ). The plasmid was cut by MscI and self-ligated to contain an insert lacking MscI-MscI ( $288 \mathrm{bp}$ ). The deletion-mutated cRNAs were synthesized using $T_{7}$ RNA polymerase (Takara Shuzo) after being linearized with Hind III. Total RNA $(500 \mathrm{ng})$ and the deletion-mutated cRNA ( $1 \mathrm{pg}$ ) were simultaneously mixed and assayed by competitive RT-PCR. Denaturing, annealing, and extension reactions were performed 25 times at $94^{\circ} \mathrm{C}$ for ${ }^{\circ} 45 \mathrm{~s}$, $60^{\circ} \mathrm{C}$ for $30 \mathrm{~s}$, and $72^{\circ} \mathrm{C}$ for $1 \mathrm{~min}$, respectively. Native AT la-R and AT 1b-R mRNA should give a 607-bp DNA fragment and the deletion mutated cRNA should give that of $419 \mathrm{bp}$. Contamination by genomic DNA in sample RNAs was circumvented by amplifying the sample RNAs directly to PCR without $R T$, in which no significant product was visible after 40 cycles. The specificity of the gene amplification was confirmed by the specific restriction digestion pattern with Hae III as reported by Iwai and Inagami (7). As an internal RNA control, 5 '-end labeled rat $\alpha$-tubulin probe was used for Northern blotting as previously reported (3). The autoradiographic signals were measured by a scanning densitometer. To quantify the AT1-R mRNA, a trace amount $(5 \mu \mathrm{Ci})$ of $\left[{ }^{32} \mathrm{P}\right] \mathrm{dCTP}$ was included in the PCR reaction mixture. The bands of interest were excised from the agarose and ${ }^{32} \mathrm{P}$ incorporation was measured in a scintillation counter. To control for the efficiency of RT-PCR amplification against tube-to-tube variation and 
the variability in the amount of input RNA, the ${ }^{32} \mathrm{P}$ count in AT1-R signal was normalized to both the ${ }^{32} \mathrm{P}$ counts in the deletion-mutated cRNA signal and the $\alpha$-tubulin counts measured by the scanning densitometer. The normalized value in an appropriate control was expressed as 1 arbitrary unit for quantitative comparison.

AT 1a-R or AT1b-R mRNA was amplified with the oligonucleotide primers specific for the respective 3 '-noncoding sequences as reported by Kitami et al. (30): sense and antisense for ATla-R, 5'-GCACACTGGCAATGTAATGC-3' and 5'-GTTGAACAGAACAAGTGACC3', respectively; and sense and antisense for AT1b-R, 5'-GCCTGCAAGTGAAGTGATTT-3' and 5'-TTTAACAGTGGCTTTGCTCC$3^{\prime}$, respectively. Denaturing, annealing, and extension reactions were performed 30 times at $94^{\circ} \mathrm{C}$ for $30 \mathrm{~s}, 58^{\circ} \mathrm{C}$ for $45 \mathrm{~s}$, and $72^{\circ} \mathrm{C}$ for $1 \mathrm{~min}$. The RT-PCR products were $385 \mathrm{bp}$ for AT la-R and $204 \mathrm{bp}$ for AT1b$R$. The specificity of gene amplification was confirmed by reading the DNA sequence by direct sequencing using assymetrical PCR (31). To determine the ratio of the AT1a-R and AT1b-R mRNA levels, a trace amount $(5 \mu \mathrm{Ci})$ of $\left[{ }^{32} \mathrm{P}\right] \mathrm{dCTP}$ was included in the PCR, then the resultant amplified fragments were excised from the gel and the incorporated ${ }^{32} \mathrm{P}$ counts were measured in a scintillation counter.

Nuclear run-off transcription assay. Nuclei were prepared from dexamethasone-treated or control cardiac fibroblasts and a run-off assay was performed as described elsewhere (32). Nuclei $\left(3-5 \times 10^{7}\right)$ were incubated for $20 \mathrm{~min}$ at $30^{\circ} \mathrm{C}$ in the presence of $50 \mathrm{mM}$ Tris, $\mathrm{pH}$ 7.9, $100 \mathrm{mM} \mathrm{KCl}, 12.5 \%$ glycerol, $6 \mathrm{mM} \mathrm{MgCl}_{2}, 0.2 \mathrm{mM}$ EDTA, 0.5 $\mathrm{mM}$ DTT, $4 \mathrm{mM}$ of ATP, GTP, and CTP, $1 \mathrm{U} / \mu \mathrm{l}$ RNAsin, and 200 $\mu \mathrm{Ci}$ of $\left[\alpha-{ }^{32} \mathrm{P}\right] \mathrm{UTP}$. After RNase-free DNase I and proteinase K digestion, the reaction products were extracted with guanidinium isothiocyanate (4 M) and phenol/chloroform, and unincorporated $\left[\alpha-{ }^{32} \mathrm{P}\right]$ UTP was removed by trichloroacetic acid precipitation and filtration. The radiolabeled RNA $\left(2-3 \times 10^{7} \mathrm{cpm}\right)$ was dissolved in $1 \mathrm{ml}$ of hybridization solution ( $50 \%$ formamide, $5 \times$ SSC, $160 \mathrm{mM}$ Tris, $\mathrm{pH} 7.5,1$ $\times$ Denhardt's solution, $0.5 \%$ SDS, $7.5 \%$ Dextran) and hybridized at $42^{\circ} \mathrm{C}$ for $48 \mathrm{~h}$ with $5 \mu \mathrm{g}$ of linearized pBluescript II KS(-) plasmid, immobilized to a nylon membrane, containing rat ATla-R cDNA fragment ( 3 ) or rat $\beta$-actin cDNA (a kind gift from Dr. Yasukiyo Mori, Kansai Medical University, Japan). After washing the membrane in 2 $\times \mathrm{SSC}+0.1 \% \mathrm{SDS}$ at $65^{\circ}$ for $1 \mathrm{~h}, 0.2 \times \mathrm{SSC}+0.1 \% \mathrm{SDS}$ at $37^{\circ} \mathrm{C}$ for 30 min in the presence of $10 \mu \mathrm{g} / \mathrm{ml} \mathrm{RNase} \mathrm{A}$, and $0.2 \times \mathrm{SSC}$ at $37^{\circ} \mathrm{C}$ for 30 min, the bound radioactivity was determined by scintillation counting.

Transcription stability analysis. The stability of ATla receptor mRNA in dexamethasone-treated and control cardiac fibroblast was measured by incubating the cells with $5 \mu \mathrm{g} / \mathrm{ml}$ actinomycin $\mathrm{D}$ to block transcription as reported previously (33). After various periods of incubation, total RNA $(2 \mu \mathrm{g})$ was isolated from individual dishes and RT-PCR was performed using the primers specific for AT1a receptor gene without deletion mutated cRNA.

Immunocytochemistry. The contamination of cardiomyocytes was examined by means of the immunofluorescent staining using a mouse monoclonal antibody against desmin (Sigma Chemical Co., St. Louis, MO), a cytochemical protein of cardiomyocytes as described by Dostal et al. (20). The staining procedures were performed on cells seeded on glass coverslips. After aspirating of culture media, cells were washed three times with $100 \mathrm{mM}$ glycine in PBS ( $12.3 \mathrm{mM} \mathrm{NaH}_{2} \mathrm{PO}_{4}, 3.17$ $\mathrm{mM} \mathrm{KH}_{2} \mathrm{PO}_{4}, 123.3 \mathrm{mM} \mathrm{NaCl}, \mathrm{pH} \mathrm{7.4)}$ and fixed for $10 \mathrm{~min}$ at $22^{\circ} \mathrm{C}$ with Formalin fixative ( $3.7 \%$ formamide, $244 \mathrm{mM}$ sodium acetate, $\mathrm{pH}$ 7.5). The cells were washed three times with $100 \mathrm{mM}$ glycine in PBS and soaked in $0.05 \%$ Triton X-100 in PBS for $10 \mathrm{~min}$. The cells were washed and incubated with the solution containing $50 \mathrm{mM}$ Tris $\mathrm{pH}$ $7.4,100 \mathrm{mM} \mathrm{NaCl}, 5 \%$ nonfat dry milk for $10 \mathrm{~min}$, after which the cells were incubated for $1 \mathrm{~h}$ with anti-desmin monoclonal antibody (diluted $1: 50$ ) at $37^{\circ} \mathrm{C}$ and treated with goat anti-mouse IgG-fluorescein isothiocyanate (Sigma Chemical Co.). The secondary antibody was titrated to prevent nonspecific background fluorescence. The cells were rinsed in deionized water and placed cell-side down in mounting solution $(90 \%$ glycerol in PBS) containing $0.1 \%$-phenylenediamine added to reduce photobleaching of the fluorescent stains during microscopy.

Reagents and statistical methods. All reagents were purchased from Sigma Chemical Co. unless otherwise indicated below. Results are expressed as mean \pm SEM. Analysis of variance and the Newman-Keuls test were used for multigroup comparisons. Values of $P<.05$ were considered statistically significant.

\section{Results}

The AngII binding assay was performed with ${ }^{125}$ I-AngII for cardiac fibroblasts and with ${ }^{125} \mathrm{ISSar}^{1} \mathrm{Ile}^{8}$ AngII for cardiomyocytes, because it has been shown that using these different ${ }^{125} \mathrm{I}$ ligands, neonatal rat cardiac fibroblasts (22) or cardiomyocytes (29) have a single class of AngII binding sites, respectively. The use of ${ }^{125}$ I-AngII to cardiomyocytes from 1-d-old rats yielded two class of binding sites with high $\left(K_{\mathrm{d}}=0.78 \pm 0.06 \mathrm{nM}, n=3\right)$ and low $\left(K_{\mathrm{d}}=6.2 \pm 0.2 \mathrm{nM}, n=3\right)$ affinities in the Scatchard plots. The $K_{\mathrm{d}}$ value of cardiomyocytes (Table I), determined by ${ }^{125} \mathrm{I}-\mathrm{Sar}^{1} \mathrm{Ile}^{8}$ AngII, was very similar to that of high-affinity sites determined by the use of ${ }^{125}$ I-AngII, and the potency of unlabeled AngII in competing for ${ }^{125} \mathrm{I}$-AngII binding $\left(\mathrm{IC}_{50}\right.$ $=1.3 \mathrm{nM})$ and ${ }^{125} \mathrm{I}-\mathrm{Sar}^{1}, \mathrm{Ile}^{8}$ AngII binding $\left(\mathrm{IC}_{50}=1.1 \mathrm{nM}\right)$ was almost same, suggesting that ${ }^{125} \mathrm{I}-\mathrm{Sar}^{1} \mathrm{Ile}^{8}$ AngII recognized the same binding site as ${ }^{125}$ I-AngII. These data are in good agreement with the results by Rogers et al. (29) using the microsomal fraction from neonatal rat cardiomyocytes.

Equilibrium binding of ${ }^{125} \mathrm{I}$-ligands was attained after 60 min at $23^{\circ} \mathrm{C}$ in cardiac fibroblasts and cardiomyocytes pre-

Table I. Summary of Scatchard Analysis Data of AngII Binding Assay

\begin{tabular}{|c|c|c|c|c|c|c|}
\hline & \multicolumn{2}{|c|}{ Embryonic day 19} & \multicolumn{2}{|c|}{$1-d$ neonate } & \multicolumn{2}{|c|}{ 7-d neonate } \\
\hline & $K_{\mathrm{d}}$ & $B_{\max }$ & $K_{d}$ & $B_{\max }$ & $K_{\mathrm{d}}$ & $B_{\max }$ \\
\hline & $n M$ & fmol/mg protein & $n M$ & fmol/mg protein & $n M$ & fmol/mg protein \\
\hline \multicolumn{7}{|l|}{ Cardiac fibroblasts } \\
\hline AngII & $0.97 \pm 0.1$ & $826 \pm 52$ & $0.93 \pm 0.1$ & $588 \pm 43^{*}$ & $0.95 \pm 0.1$ & $603 \pm 48^{*}$ \\
\hline \multicolumn{7}{|l|}{ Cardiomyocytes } \\
\hline $\mathrm{Sar}^{1} \mathrm{Ile}^{8}$ AngII & $0.68 \pm 0.04$ & $465 \pm 51$ & $0.61 \pm 0.1$ & $357 \pm 61^{*}$ & $0.64 \pm 0.1$ & $342 \pm 40 *$ \\
\hline
\end{tabular}

Cells on 35-mm plates were incubated with $0.05 \mathrm{nM}^{125} \mathrm{I}$-AngII for cardiac fibroblasts or $0.05 \mathrm{nM}^{125} \mathrm{I}_{-}$Sar $^{1}$ Ile ${ }^{8}$ AngII for cardiomyocytes in the presence of varying concentrations of unlabeled ligands. The binding data were determined by Scatchard analysis. An experiment was performed using cell plates in duplicate from a single preparation. Data shown are the mean \pm SEM of the values from three separate experiments. ${ }^{*} P$ $<0.05$ compared with the values in embryonic day 19. 

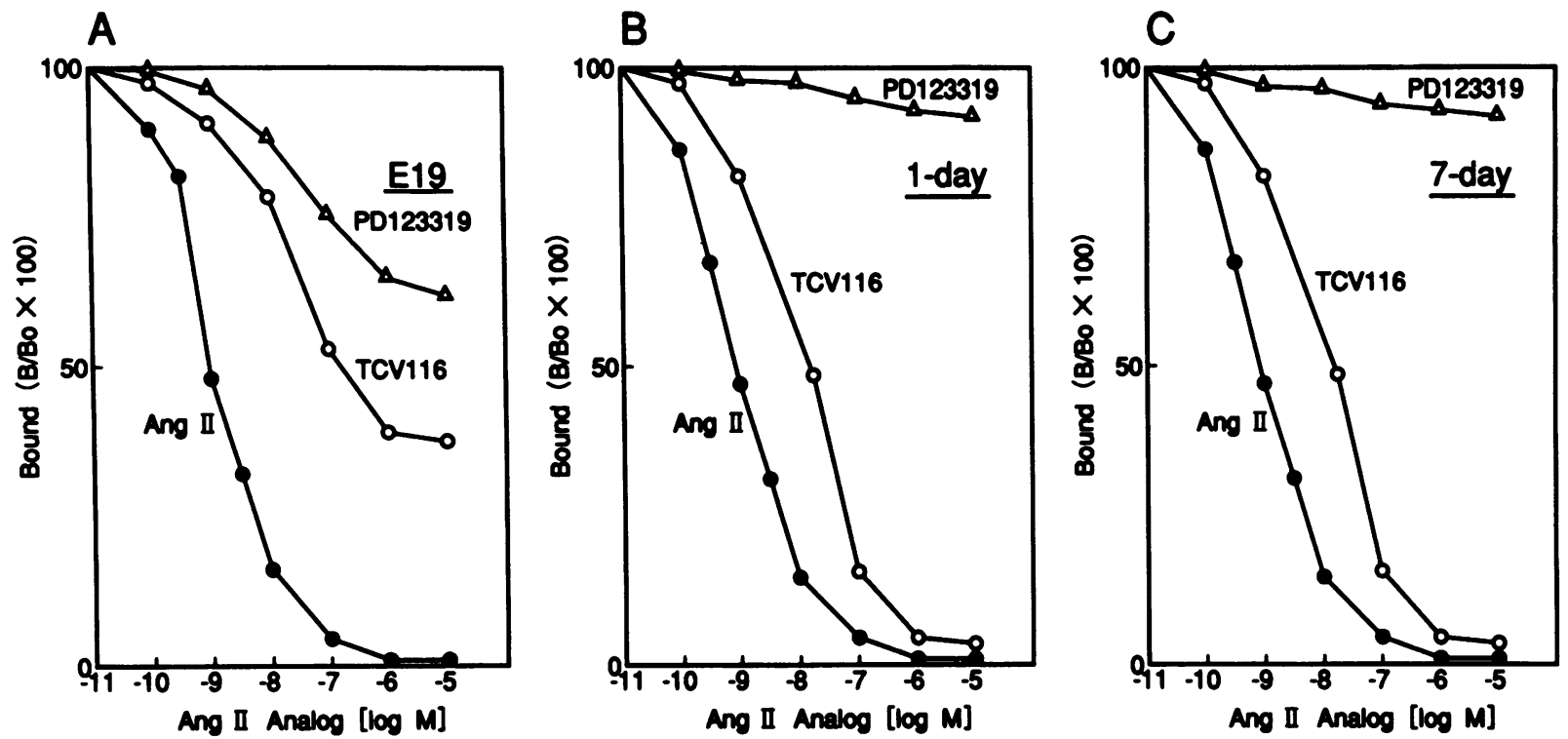

Figure 1. Competition curves showing ligand specificity for ${ }^{125}$ I-AngII binding to embryonal day 19 (E19) and neonatal rat (1 and $7 \mathrm{~d}$ ) cardiac fibroblasts. Cells on $35-\mathrm{mm}$ plates were incubated with $0.05 \mathrm{nM}^{125} \mathrm{I}$-AngII for $60 \mathrm{~min}$ in the presence of varying concentrations of nonlabeled AngII, TCV116 (AT1 receptor antagonist), and PD123319 (AT2 receptor antagonist). An experiment was performed at each concentration using the cell plates in duplicate from a single preparation. Each point in competition curves represents the mean of values from three separate experiments and the deviation range is within $10 \%$.

pared from embryonal day 19 (E19) and neonatal rat hearts ( 1 and $7 \mathrm{~d}$ ), and their saturable specific binding represented $70-95 \%$ of total bindings over a range of radioligand concentrations $(0.05-10 \mathrm{nM})$. Nonradiolabeled AngII and $\mathrm{Sar}^{1} \mathrm{Ile}^{8}-$ AngII competed for the bindings of $0.05 \mathrm{nM}^{125}$-ligands with high affinity for cardiac fibroblasts and cardiomyocytes (Figs. 1 and 2). Scatchard analyses of the data were linear and hence consistent with the presence of a single class of AngII-binding sites ( summarized in Table I), as reported previously $(22,29)$. The subtype of AngII receptor in cardiac fibroblasts and car- diomyocytes was determined by the ability of the specific antagonists to inhibit the binding of ${ }^{125}$ I-ligands to the cells (Figs. 1 and 2). In the E19 cardiac fibroblasts the AT1-R antagonist (TCV116) inhibited the binding by $61 \pm 2 \%$ at a concentration of $1 \mu \mathrm{M}$ with an $\mathrm{IC}_{50}$ of $32 \pm 5 \mathrm{nM}$, while the AT2-R antagonist (PD123319) caused a $38 \pm 2 \%$ inhibition at $1 \mu \mathrm{M}$. In the 1 - and 7-d cardiac fibroblasts, the AT1-R antagonist competed strongly and displaced the binding by $95 \pm 3 \%$ at a concentration of $1 \mu \mathrm{M}$, whereas the AT2-R antagonist was a very weak competitor. Competitive binding was also studied in the car-
A

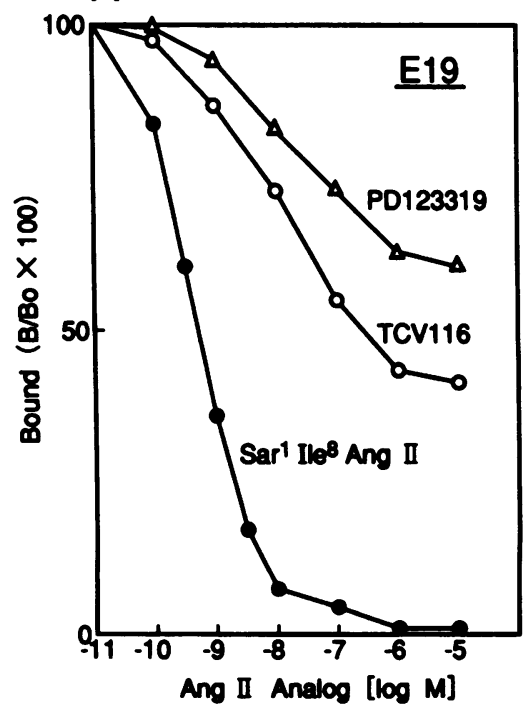

B

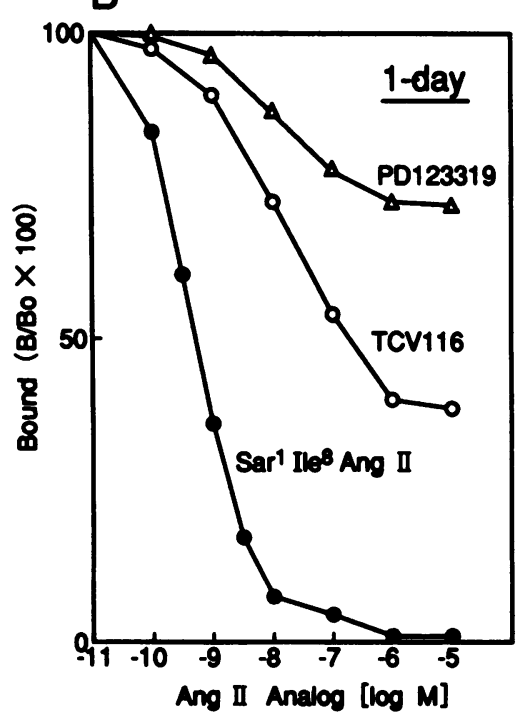

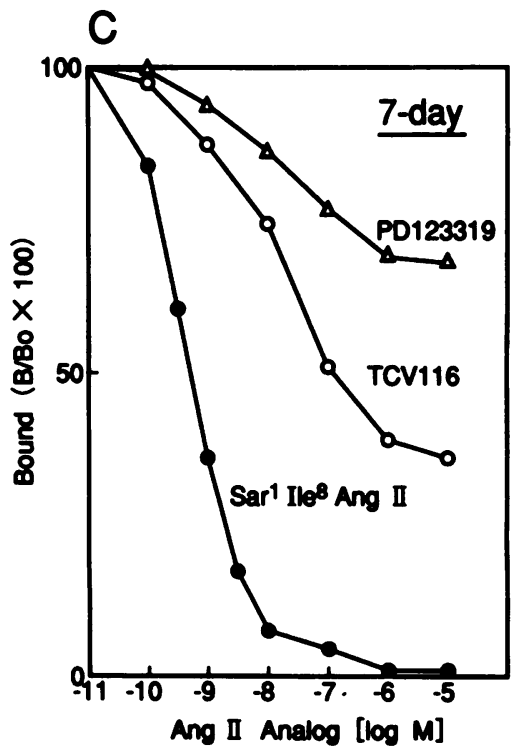

Figure 2. Competition curves showing ligand specificity for ${ }^{125} \mathrm{I}-S a r^{1} \mathrm{Ile}^{8}$ AngII binding to embryonal day 19 (E19) and neonatal rat (1 and $7 \mathrm{~d}$ ) cardiomyocytes. Cells on $35-\mathrm{mm}$ plates were incubated with $0.05 \mathrm{nM}^{125} \mathrm{I}-\mathrm{Sar}^{1} \mathrm{Ile}^{8}$ AngII for 60 min in the presence of varying concentrations of nonlabeled Sar ${ }^{1} \mathrm{Ile}^{8}$ AngII, TCV116 (AT1 receptor antagonist), and PD123319 (AT2 receptor antagonist). An experiment was performed at each concentration using the cell plates in duplicate from a single preparation. Each point in competition curves represents the mean of values from three separate experiments and the deviation range is within $10 \%$. 
diomyocytes. As shown in Fig. 2, in contrast to the data from the cardiac fibroblasts, cardiomyocytes substantially expressed both AT1-R and AT2-R through embryonal and neonatal stages: the AT1 antagonist $(10 \mu \mathrm{M})$ inhibited the binding by $59 \pm 3 \%$ (E19), $62 \pm 4 \%$ ( $1 \mathrm{~d}$ ), and $63 \pm 4 \%$ ( $7 \mathrm{~d}$ ), while the AT2 antagonist $(10 \mu \mathrm{M})$ caused $40 \pm 4 \%$ (E19), $29 \pm 3 \%$ ( $1 \mathrm{~d})$, and $31 \pm 4 \%$ ( 7 d) inhibitions, respectively.

Fig. $3 A$ shows the change in the AngII receptor density and the subtype expression profiles in E19 and 1-d neonatal rat cardiac fibroblasts. The AngII receptor densities in E19 cardiac fibroblasts are significantly higher $(P<0.01,1.4$-fold $)$ as compared with those in 1-d fibroblasts, while AT1-R densities do not significantly change $(524 \pm 31 \mathrm{fmol} / \mathrm{mg}$ protein at E19 to $549 \pm 33 \mathrm{fmol} / \mathrm{mg}$ protein at $1 \mathrm{~d}$ ) and AT2-R densities are dramatically decreased ( $305 \pm 23 \mathrm{fmol} / \mathrm{mg}$ protein to $41 \pm 12 \mathrm{fmol} /$ $\mathrm{mg}$ protein) in 1-d neonates. The binding affinity was similar in E19 and neonatal rat cardiac fibroblasts (Table I). This indicates that the remarkable decrease in the AngII receptor density that occurs in 1-d cardiac fibroblasts is mainly attributed to the change in AT2-R expression. The unchanged AT1-R ex- pression during embryonic and neonatal period was examined at the mRNA level using quantitative RT-PCR, because of the low level of AT1-R mRNA expression in the cardiac fibroblasts and cardiomyocytes. The validity of the quantitative RT-PCR analysis for AT1-R gene has already been established by our group (3) and by Iwai et al. (34). As shown in Fig. $3 \mathrm{~B}$, the RT-PCR assay indicates that the AT1-R mRNA levels in E19 and 1-d rat cardiac fibroblasts are very similar, which is consistent with the results of the binding assay. On the other hand, the AT1-R has two subtypes (AT1a-R and AT1b-R) with high homology as well as similar binding and functional characteristics $(7,13)$. Because the PCR primers used in the RT-PCR assay for AT1-R mRNA levels are designed from the oligonucleotides common to AT1a-R and AT1b-R cDNA sequences, the amplified AT1-R signals reflect both AT1a-R and AT1b-R mRNA levels. Therefore, we designed primers specific for ATla-R or ATlb-R sequences to examine the subtype mRNA levels. As shown in Fig. $3 C$, the embryonal day 19 and neonatal rat cardiac fibroblasts expressed both AT1a-R and AT1b-R mRNAs. The AT1a-R mRNA level is higher (approximately
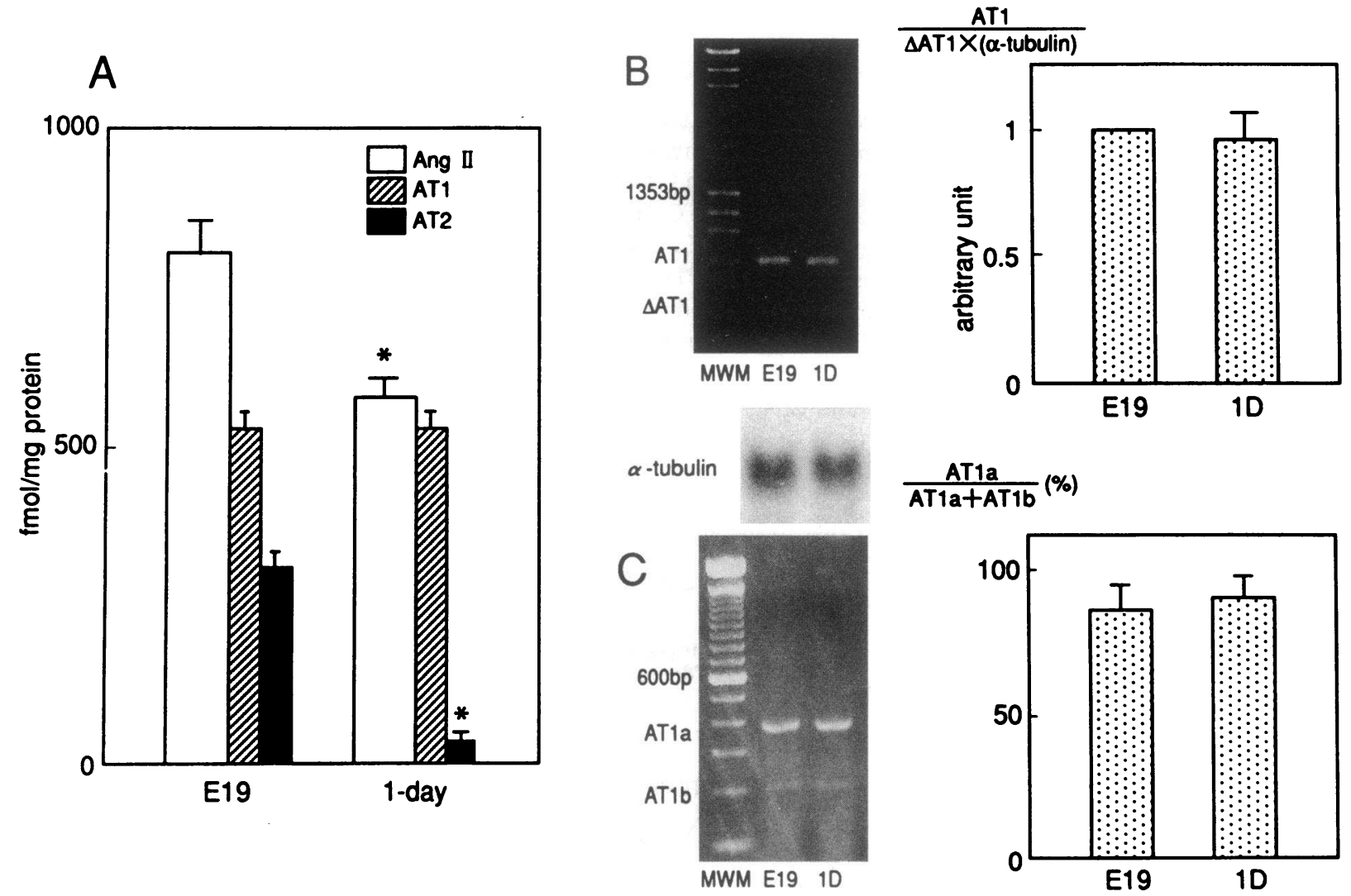

Figure 3. Developmental regulation of AT1 and AT2 receptor expression in embryonal day 19 (E19) and 1-d neonatal rat cardiac fibroblasts. (A) AngII receptor density was calculated from the Scatchard analysis of the competitive binding curves shown in Fig. 1. Specific ${ }^{125}$ I-AngII binding sensitive to TCV-116 or PD123319 was estimated as AT1 or AT2 receptors, respectively (3). The experimental conditions, data numbers, and statistical methods are same as those in Fig. $1 .{ }^{*} P<0.01$ vs. E19 values. $(B)$ Total RNA $(500 \mathrm{ng})$ was reverse-transcribed with deletion mutated cRNA ( $\triangle \mathrm{AT} 1,1 \mathrm{pg})$ and resultant cDNA mixtures were amplified by PCR in the presence of $\left[{ }^{32} \mathrm{P}\right] \mathrm{dCTP}$. The PCR products loaded onto a $1 \%$ agarose gel and autoradiographic signals ( $10 \mu \mathrm{g}$ of total RNA) from Northern blots using $\alpha$-tubulin are shown. The incorporated ${ }^{32} \mathrm{P}$ counts in AT1 signals were normalized to those in $\triangle \mathrm{AT} 1$ and $\alpha$-tubulin autoradiographic counts measured using a densitometer. The normalized value in E19 fibroblasts was arbitrarily expressed as 1 unit. $(C)$ Total RNA ( $500 \mathrm{ng}$ ) was reverse-transcribed and amplified with AT 1a and AT1b specific primers in the presence of $\left[{ }^{32} \mathrm{P}\right] \mathrm{dCTP}$. The resultant PCR products were loaded onto a $2 \%$ agarose gel. The ratio of the expression level of AT la and ATlb was calculated as (the radioactivity of 385-bp fragment/the radioactivity of 204-bp fragment) $\times$ ( 90 [GC content of 204-bp fragment]/171 [GC content of 385-bp fragment]). An experiment was performed using total RNA from cells obtained by a single preparation. All data shown are the means \pm SEM of three separate experiments. Abbreviation: MWM, molecular weight marker 
ninefold) than that of AT1b-R in E19 fibroblasts and this expression pattern was unchanged throughout the embryonal and neonatal periods.

Fig. $4 \mathrm{~A}$ shows the changes in AngII receptor density and subtype in E19 and 1-day rat cardiomyocytes: AngII receptor densities are significantly $(P<0.05)$ decreased from $465 \pm 51$ (E19) to $357 \pm 61 \mathrm{fmol} / \mathrm{mg}$ protein (1-d), whereas the proportion of AT1-R is unchanged and the AT2-R density is decreased (from $178 \pm 14$ to $87 \pm 9 \mathrm{fmol} / \mathrm{mg}$ protein). This developmental regulation profile of subtype expression is comparable with that in the cardiac fibroblasts except that the proportion of AT2-R expression is more remarkably reduced in 1-d cardiac fibroblasts. As shown in Fig. $4 \mathrm{~B}$, the AT1-R mRNA levels in E19 and 1-d rat cardiomyocytes were not significantly changed, which was in agreement with the results of the binding assay. The AT 1a-R and ATlb-R mRNA levels in the cardiomyocytes were analyzed by RT-PCR (Fig. $4 C$ ). The ratios of AT1a-R mRNA to AT1a-R + AT1b-R mRNAs were $42 \pm 7 \%$ (E19) and $43 \pm 6 \%$ (1-d), suggesting that the AT1b-R mRNA level expressed in cardiomyocytes slightly predominates over that of ATla-R in contrast to the expression profile in cardiac fibroblasts.

It has been reported that the proportion of AT1-R and AT2-R subtype expression in embryonal rat skin fibroblasts changes during culture (35). As described in Methods, the car- diac fibroblasts obtained by pre-plating were maintained for 2 d, passaged with trypsin, then seeded on plates. Fig. 5 shows the expression profiles of the AT1-R and AT2-R subtypes in E19 and 1-d cardiac fibroblasts during culture. The total AngII receptor densities did not significantly change and the proportions of AT1-R and AT2-R remained constant for $8 \mathrm{~d}$ in culture after the second dispersion. The ATla-R and AT1b-R mRNA levels were also unchanged during the culture (data not shown). Thus, unlike the embryonal rat skin fibroblasts, the embryonal and neonatal cardiac fibroblasts stably expressed AT1-R (including AT1a and AT1b) and AT2-R during culture. Because cardiac fibroblast- and cardiomyocyte-rich cultures were potentially cross-contaminated, staining with a monoclonal antibody against desmin, a cytoskeletal protein of cardiomyocytes, was used to identify cardiomyocytes. Fibroblast-rich cultures were relatively free of cardiomyocytes and cardiomyocyte-rich cultures were contaminated with about 5-10\% fibroblasts (data not shown), consistent with the previous studies $(20,22,24)$.

To investigate the effects of glucocorticoids on AngII receptors, 1-d cardiac fibroblasts were incubated with $1 \mu \mathrm{M}$ dexamethasone for 4-24 h. As shown in Fig. 6, the AngII receptor density was significantly increased after 8-24 h of exposure to dexamethasone and progressively increased by $\sim 1.8$-fold at $24 \mathrm{~h}$, while the $K_{\mathrm{d}}$ values did not significantly change during the

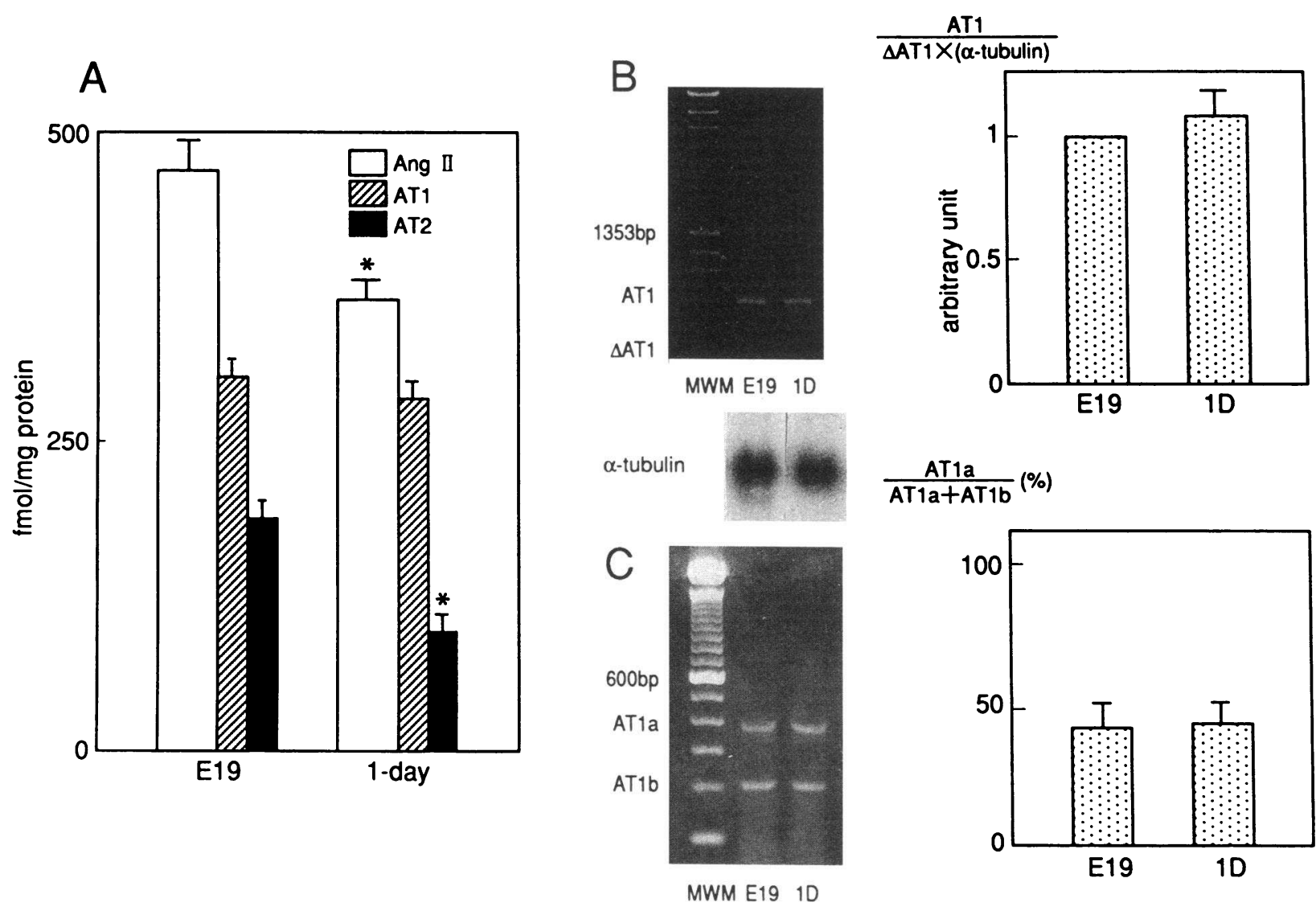

Figure 4. Developmental regulation of AT1 and AT2 receptor expression in embryonal day 19 (E19) and 1-d neonatal rat cardiomyocytes. (A) The AngII receptor density and proportion of AT1 and AT2 were determined as described in Fig. $3 \mathrm{~A}$. The experimental conditions, data numbers, and statistical methods are same as those in Fig. $1 .{ }^{*} P<0.01$ vs. E19 value. $(B)$ AT1-R mRNA levels were determined by reverse-transcriptase PCR as described in Fig. $3 B$. (C) AT1a-R and AT1b-R mRNA levels were evaluated in the way same as described in Fig. $3 C$. An experiment was performed using total RNA from cells obtained by a single preparation. All data shown are the means \pm SEM of three separate experiments. Abbreviation: MWM, molecular weight marker 

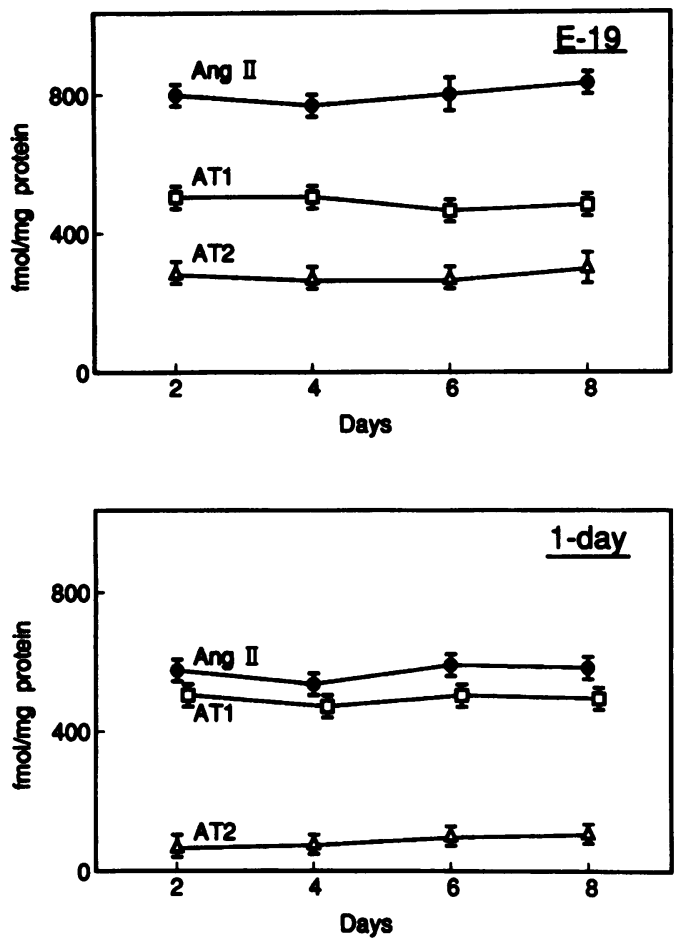

Figure 5. Changes in the expression of the AngII and AT1 and AT2 receptors in cultured embryonal day 19 (E19) and 1-d cardiac fibroblasts. The cells obtained by preplating were cultured for $2 \mathrm{~d}$ in the presence of $10 \%$ FCS + DMEM, dispersed with trypsin, then seeded. After a 2-d culture with $10 \%$ FCS + DMEM (day 2), the medium was exchanged to serum-free DMEM at the indicated time and the binding assay was performed $1 \mathrm{~d}$ later. An experiment was performed at each time point using the cell plates in duplicate from a single preparation. All data shown are the means \pm SEM of three separate experiments.

exposure. It should be noted that AT1-R expression was increased by dexamethasone, whereas AT2-R expression was unaffected at $24 \mathrm{~h}$ (Fig. $7 \mathrm{~A}$ ). The steady-state mRNA level of AT1-R was measured by RT-PCR (Fig. $7 B$ ). Since the $\alpha$-tubulin mRNA level was significantly unchanged throughout the experimental period, we used $\alpha$-tubulin mRNA as an internal RNA control. The relative value normalized with deletion mutated cRNA and $\alpha$-tubulin signals indicated that the increase in the AT1-R mRNA level was $1.91 \pm 0.12$-fold at $24 \mathrm{~h}$. The effects of dexamethasone on AT 1a-R and AT1b-R mRNA levels were studied (Fig. $7 C$ ). AT1a-R mRNA accumulation was exclusively induced as compared to that in the absence of dexamethasone, whereas changes in AT1b-R mRNA were not significant. RU38486, a specific glucocorticoid antagonist, completely inhibited the increases of ATla-R at the protein and mRNA levels induced by dexamethasone (Fig. 7, $A$ and $B$ ).

We determined whether dexamethasone increased AT 1a-R mRNA levels through a transcriptional or a posttranscriptional mechanism. To investigate this, a nuclear run-off transcription assay was performed and the stability of AT1a-R mRNA was examined. As shown in Fig. $8 A$, the transcriptional rate of ATla-R gene relative to that of $\beta$-actin gene increased $1.96 \pm 0.23$-fold in dexamethasone-treated cells. The rate of transcription of $\beta$-actin gene was not altered with dexamethasone as previously reported (36). This change corresponded with the increase in AT1a-R mRNA levels evaluated by RTPCR. The AT1a-R mRNA turnover was examined by inhibit-

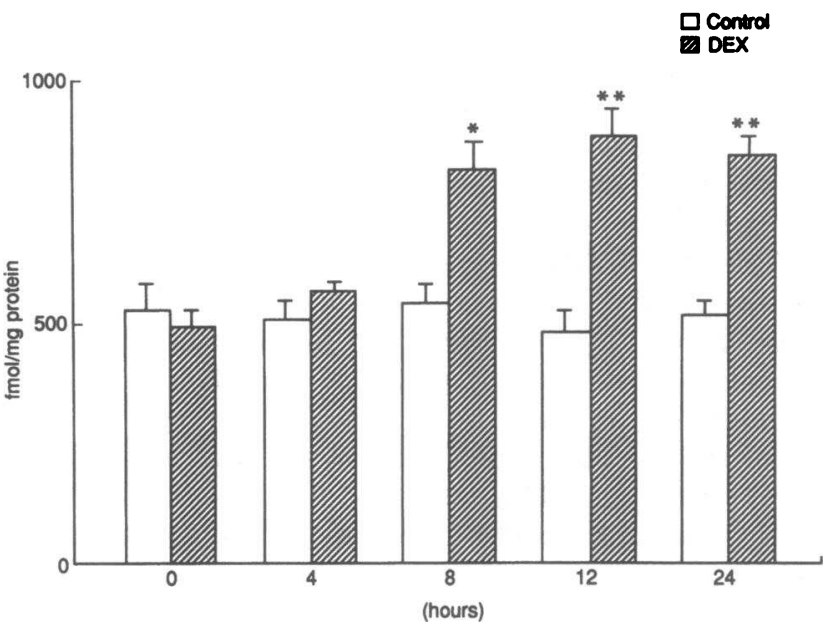

Figure 6. Time course of changes in the number of AngII receptors induced by dexamethasone $(D E X)$. 1-d cardiac fibroblasts were exposed to dexamethasone $(1 \mu \mathrm{M})$ for 4-24 h. An experiment was performed at each time point using the cell plates in duplicate from a single preparation. The data shown are the means \pm SEM of three separate experiments. ${ }^{*} P<0.05,{ }^{* *} P<0.01$ vs. controls.

ing new mRNA transcription with actinomycin $\mathrm{D}$ (Fig. $8 \mathrm{~B}$ ). A half-life of $18 \pm 0.7 \mathrm{~h}$ for AT 1a-R transcript was obtained in the absence of the steroid. The half-life was unchanged in the presence of dexamethasone up to $36 \mathrm{~h}$.

\section{Discussion}

The renin-angiotensin system is an important determinant of cardiovascular homeostasis. Recent evidence indicates that AngII is involved in mitogenesis and/or hypertrophy as well as in stimulating the heart rate and affecting cardiac contractility (14). For example, AngII stimulates hypertrophy in adult rat cardiomyocytes and expression of the early growth response gene in adult rat cardiomyocytes $(24,37)$. A series of studies by Baker and co-workers have revealed that rat neonatal cardiac fibroblasts express the functional AngII receptors, AngI, AngII, and $\mathrm{ACE}$ as a component of the local renin-angiotensin system in the heart $(20,22)$. Several animal studies have shown that treatment with an ACE inhibitor prevents myocardial fibrosis in a rat model with renovascular hypertension (38) and with induced myocardial infarction (39). In the latter study, collagen accumulation and DNA synthesis were prevented by the ACE inhibitor. This evidence suggests that cardiac fibroblasts are a target of AngII, and that AngII plays a role in the structural remodeling of the cardiac interstitium by exerting a proliferative effect on fibroblasts.

Our present data showed for the first time, that rat cardiac fibroblasts in culture consistently express AT 1a-R rather than AT $1 \mathrm{~b}-\mathrm{R}$ during development from the late embryo to the neonate, and that the expression of AT2-R is dramatically repressed immediately after birth. An increase in the total number of AngII receptors in embryonal rat cardiac fibroblasts was shown to be due to an increase in the number of AT2-R. In contrast, the substantial expression of both AT1-R and AT2-R in the cardiomyocytes in culture was maintained during development, in which the expression of AT2-R is significantly increased in E19 cardiomyocytes as compared to that during the neonatal period, resulting in an increase of total AngII receptor 

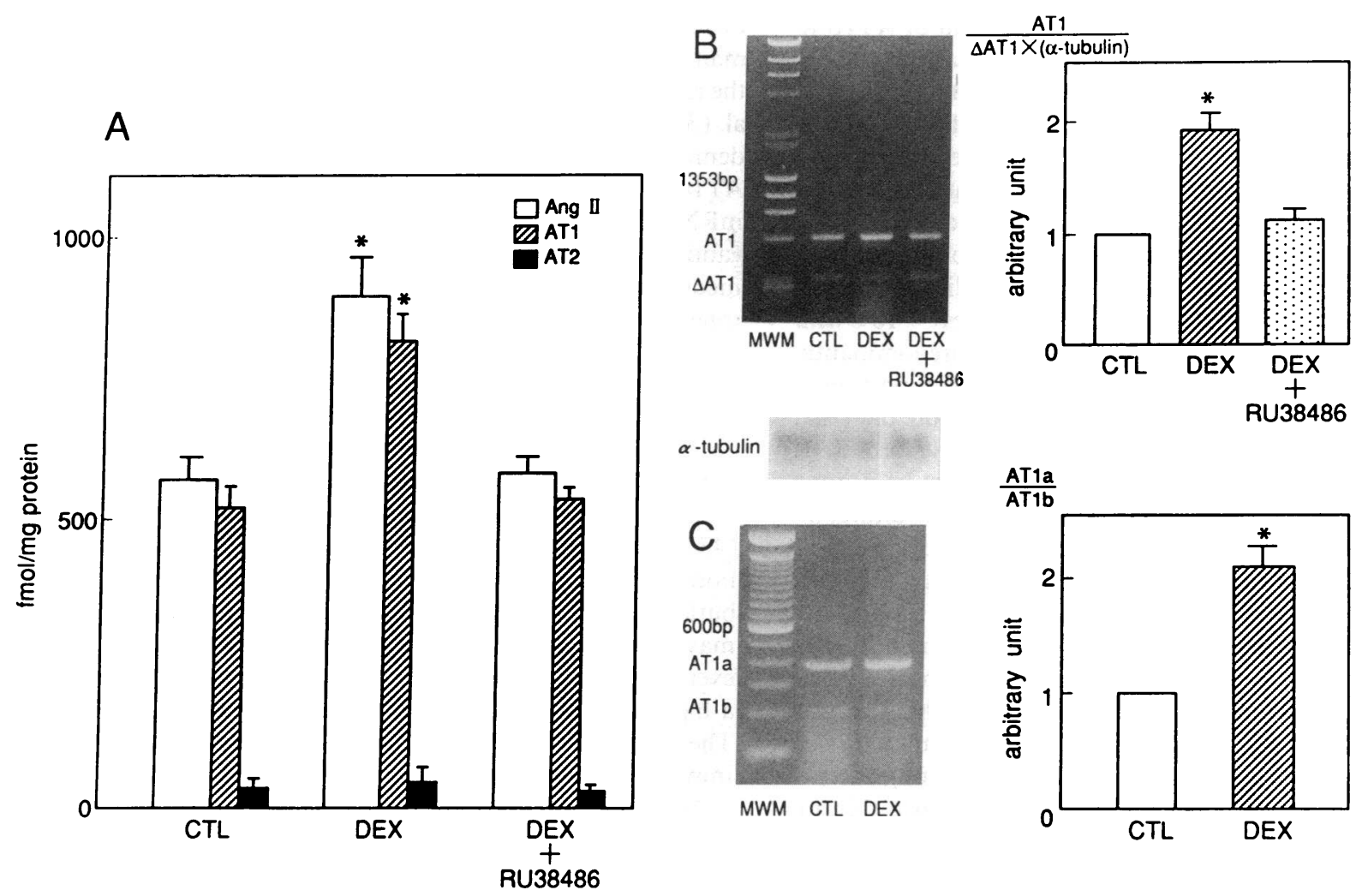

Figure 7. Changes in AngII, AT1 and AT2 receptor numbers, and mRNA levels induced by dexamethasone ( $D E X)$. 1-day cardiac fibroblasts were incubated with DEX $(1 \mu \mathrm{M})$ or DEX $(1 \mu \mathrm{M})+\operatorname{RU} 38486(10 \mu \mathrm{M}$, added 30 min before $)$ for $24 \mathrm{~h}$. $(A)$ The AngII receptor numbers and the proportion of AT1 and AT2 receptors were determined as described in Fig. $3 A$. The experimental conditions, data numbers, and statistical methods are same as those in Fig. $1 .{ }^{*} P<0.05$ vs. control $(C T L)$ value. $(B)$ Reverse-transcriptase PCR of AT1 receptor mRNA levels induced by dexamethasone $(1 \mu \mathrm{M})$ for $24 \mathrm{~h}$. The AT1 signals were arbitrarily normalized to deletion-mutated cRNA ( $\triangle \mathrm{AT} 1)$ and $\alpha$-tubulin Northern blot signals as described in Fig. $3 B .{ }^{*} P<0.01$ vs. CTL value. $(C)$ Reverse-transcriptase PCR of the ATla and AT1b mRNA levels induced by dexamethasone $(1 \mu \mathrm{M})$ for $24 \mathrm{~h}$. The ratio of ATla-R and AT1b-R was calculated in the way same as Fig. $3 C$. ${ }^{*} P<0.05$ vs. CTL value. An experiment was performed using total RNA from cells obtained by a single preparation. All data shown are the means \pm SEM of three separate experiments. Abbreviation: MWM, molecular weight marker.
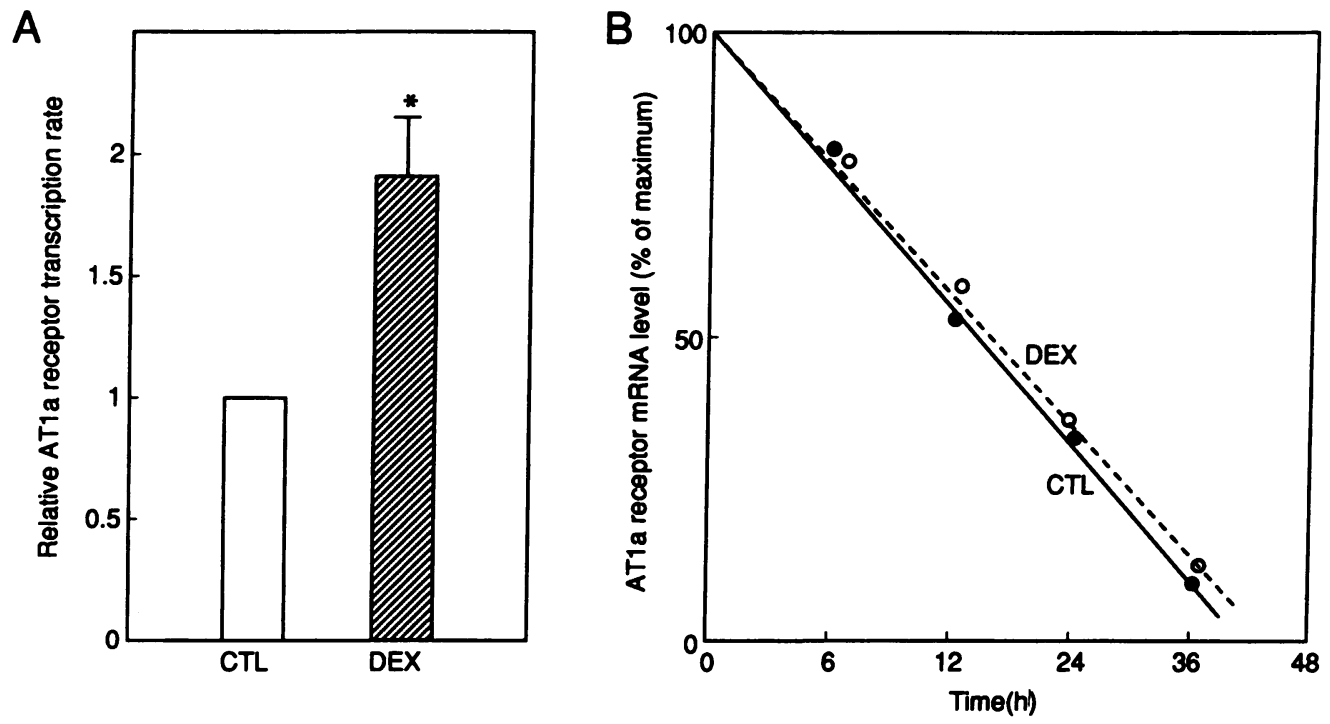

Figure 8. $(A)$ Effects of dexamethasone ( $D E X)$ on transcription rate of the AT la receptor gene. 1-d cardiac fibroblasts were incubated in DMEM containing 5\% FCS without (CTL) or with DEX $(1 \mu \mathrm{M})$ for $24 \mathrm{~h}$. The nuclei were isolated and incubated in the presence of $\left[{ }^{32} \mathrm{P}\right]$ UTP as described in Methods. The [ $\left.{ }^{32} \mathrm{P}\right] \mathrm{RNA}$ was isolated and hybridized to plasmid DNAs $(5 \mu \mathrm{g} /$ dot $)$ containing ATla$\mathrm{R}$ or $\beta$-actin cDNA. The transcription rates were expressed relative to the $\beta$-actin transcription rate and the values in CTL were normalized to 1 arbitrary unit. An experiment was performed using cells from a single preparation. The data shown are the means \pm SEM of three separate experiments. ${ }^{*} P<0.05$ vs. CTL. $(B)$ Stability of AT la receptor mRNA was estimated by inhibiting gene transcription with actinomycin D. 1-d cardiac fibroblasts were incubated in the medium without (CTL) or with DEX ( $1 \mu \mathrm{M})$ for $24 \mathrm{~h}$, and the medium was replaced with DMEM containing actinomycin D (5 $\mu \mathrm{g} / \mathrm{ml})$ without (CTL) or with DEX $(1 \mu \mathrm{M})$ for the indicated periods. The decrease in the AT1a receptor mRNA abundance was detected by reverse-transcriptase PCR method using ATla primers without deletion mutated cRNA. An experiment was performed using total RNA from cells obtained by a single preparation. The data shown are the means of three separate experiments and the deviation range is within $10 \%$. 
numbers in E19 cardiomyocytes. The expression of AT1b-R mRNA in cardiomyocytes, unlike cardiac fibroblasts, predominates over the AT la-R mRNA level and this expression profile was consistently observed through the embryonal and neonatal period. A previous study (22) that used a cell preparation procedure very similar to ours, showed that the contamination of vascular smooth muscle cells in cardiac fibroblast cultures is $<5 \%$ and that there is no contamination of endothelial cells in fibroblast cultures. Because it is impossible to eliminate fibroblast contamination from cardiomyocyte cultures ( $<10 \%$ with desmin staining) and because the fibroblasts predominantly possess AT 1a-R rather than AT1b-R, the actual proportion of AT $1 b-R$ expressed in cardiomyocytes might be more than that estimated in this study. Thus, the expression profile for AT1-R (including AT1a-R and AT1b-R) and AT2-R is quite distinct between cardiac fibroblasts and cardiomyocytes in culture, indicating that the expression of AngII receptors is regulated in a cell-specific manner in the heart as well as in a subtype-specific manner.

The AT1-R mediates AngII-induced alterations in cardiovascular responses, catecholamine and aldosterone secretion, and drinking behavior (2). Although the potential function and cDNA structure of the AT2-R remains unpublished, Grady et al. (17) have suggested an AT2-R mediating effect of AngII on fetal development, by providing evidence that the AT2-R abundantly expressed in mesenchymal cells sharply decreases postparturition and that the AT1-R is consistently present in the fetus with a tissue distribution identical to that found in the adult animal. These expression profiles appear to be very similar to those observed in cardiac fibroblasts and cardiomyocytes. Such developmental changes were also reported in the human study in which ventricular AngII-binding density in 1 -d-old baby was 10 -fold higher than that in adult heart, although the receptor subtype was not determined (40). An in situ autoradiographic study has shown that the proportion of AT1-R and AT2-R in the E19 rat heart is nearly equal (4). We also revealed using a membrane binding assay, that the neonatal rat heart expresses AT1-R and AT2-R in equal amounts, and that cardiac hypertrophy stimulates expressions of both subtypes at the mRNA and protein levels (3). In addition, an AT1-R antagonist completely inhibited the development of hypertrophy, whereas the AT2-R antagonist did not affect the magnitude of hypertrophy. These accumulated findings suggest that in the rat heart, the AT2-R is important during fetal development and that the AT1-R is closely involved in the growth or hypertrophic responses of the mature heart in the postnatal period. The findings that balloon angioplasty enhances the expression of AT1-R in the neointima of the rat aorta (41) or that a venous bypass graft induced AT1-R expression in the myointimal thickening segment (42) may support our hypothesis. Further study, including molecular characterization of AT2-R would be required.

The rat AT1-R have at least two subtypes (AT1a-R and AT1b-R), which exhibit high similarity in amino acid sequence (95\% identity), binding of AngII analogues and utilization of $\mathrm{Ca}^{++}$as an intracellular second message $(7,13)$. The adrenal, pituitary, and uterus primarily express ATlb-R mRNA, whereas vascular smooth muscle, kidney, and cerebrum express primarily AT1a-R mRNA $(7,13)$. In the human study, Mauzy et al. (10) have reported that the subtype in AT1-R exists in the human gene, whereas Yoshida et al. (12) have shown that human has a single class of AT1-R gene. Thus, there are discrepant results with respect to the presence of human AT1-R subtype. In the adult rat heart, it is reported that the ratio of AT la-R mRNA to AT 1b-R mRNA is 1.2 by Iwai et al. (34) or 1.75 by Kitami et al. (30). In the present study, we demonstrated that cardiac fibroblasts exclusively express ATla-R, while in cardiomyocytes the proportion of AT lb-R mRNA is higher than that of AT1a-R mRNA. Iwai and Inagami (7) and Kakar et al. (13) have proposed that ATlb-R mediates endocrine function such as the secretion of aldosterone from the adrenal gland, and adrenocorticotropic hormone and prolactin from the pituitary gland, because of its localized distribution in the rat tissue. The cardiomyocytes secrete atrial natriuretic factor (ANF), whereas ANF granules are not present in cardiac fibroblasts $(43,44)$. It has been reported that AngII directly stimulates ANF secretion from neonatal rat cardiomyocytes, but not from cardiac fibroblasts (43). Supposing the AT1b-R could mediate endocrine function as proposed by Kakar et al. on the basis of its tissue distribution $(7,13)$, the AngII effect mediated by cardiac AT1b-R may be involved in ANF secretion from cardiomyocytes. However, this could be unlikely, because AT 1a-R and AT 1b-R have a high similarity in the receptor-mediating function $(7,13)$. The development of an AT1b-R specific antagonist would be important to establish this claim.

In most steroid-regulated genes, gene expression is mainly influenced by changing the transcription rate (45), but significant differences in the stability of mRNA such as that of ovalbumin mRNA in the presence of estrogen (46), have been reported. In the present study, the RT-PCR assay demonstrated using the primers specific for AT 1a-R or AT1b-R gene, that the ATla-R mRNA level is increased by 2.1 -fold in the presence of dexamethasone, whereas the AT1b-R mRNA level is unchanged by dexamethasone. The increase in dexamethasone-induced transcription, measured by the run-off assay, was in good agreement with the increase in AT1a-R transcript determined by the RT-PCR assay. The half-life of ATla-R transcript (Fig. $8 \mathrm{~B}$ ) or ATlb-R transcript (data not shown) was unaffected by dexamethasone. Although the AT1a-R cDNA probe used in the run-off assay could hibridize to the transcript of AT 1 b-R gene because of its highly homologous sequence ( 7 , 13 ), these findings suggest that ATla-R gene is responsive to dexamethasone at the transcriptional level and AT $1 \mathrm{~b}-\mathrm{R}$ gene is not regulated by dexamethasone. Glucocorticoids are involved in the regulation of blood pressure (27), and enhancement of vascular responsiveness has been considered one of the major contributing factors in glucocorticoid-induced hypertension (28). It has been reported that the expression of $\alpha 1 \mathrm{~B}$-adrenergic receptor (36) or vasopressin receptor (V1 subtype) (47) is also increased by dexamethasone. Since the vascular smooth muscle cells express a substantial amount of ATla-R (5), the overexpression of these vasoactive substances receptors may be involved in vascular hyperreactivity in glucocorticoid-induced hypertension such as Cushing's disease. These possibilities would require direct experimental testing in animals possibly including humans.

\section{Acknowledgments}

This study was supported in part by research grants from the Ministry of Education, Science and Culture, Japan and the Study Group of Molecular Cardiology in Japan. 


\section{References}

1. Pearch, M. J. 1977. Renin-angiotensin system: biochemistry and mechanisms of action. Physiol. Rev. 57:313-370.

2. Timmermans, P. B. M. W. M., P. C. Wong, A. T. Chiu, W. F. Herblin, P Benfield, D. J. Carini, R. J. Lee, R. R. Wexler, J. A. M. Saye, and R. D. Smith 1993. Angiotensin II receptors and angiotensin II receptor antagonists. Pharma col. Rev. 45:205-251.

3. Suzuki, J., H. Matsubara, M. Urakami, and M. Inada. 1993. Rat angiotensin II (type 1A) receptor mRNA regulation and subtype expression in the myocardial growth and hypertrophy. Circ. Res. 73:439-447.

4. Sechi, L. A., C. A. Griffin, E. F. Grady, J. E. Kalinyak, and M. Schambelan. 1992. Characterization of angiotensin II receptor subtypes in rat heart. Circ. Res. 71:1482-1489.

5. Murphy, T. J., R. W. Alexander, K. K. Griendling, M. S. Runge and K. E. Bernstein. 1991. Isolation of a cDNA encoding the vascular type-1 angiotensin II receptor. Nature (Lond.). 351:233-236.

6. Iwai, N., Y. Yamano, S. Chaki, F. Konishi, S. Bardhan, C. Tibbetts, K. Sasaki, M. Hasegawa, Y. Matsuda, and T. Inagami. 1991. Rat angiotensin II receptor: cDNA sequence and regulation of the gene expression. Biochem. Biophys. Res. Commun. 177:299-304.

7. Iwai, N., and T. Inagami. 1991. Identification of two subtypes in the rat type 1 angiotensin II receptor. FEBS (Fed. Eur. Biochem. Soc.) Lett. 177:299304.

8. Sasaki, K., T. Yamano, S. Bardhan, N. Iwai, J. Murray, M. Hasegawa, Y. Matsuda, and T. Inagami. 1991. Cloning and expression of a complementary DNA encoding a bovine adrenal angiotensin II type 1 receptor. Nature (Lond.). 351:230-233.

9. Furuta, H., D. F. Guo, and T. Inagami. 1992. Molecular cloning and sequencing of the gene encoding human angiotensin II type 1 receptor. Biochem. Biophys. Res. Commun. 183:8-13

10. Mauzy, C. A., O. Hwang, A. M. Egloff, L. H. Wu, and F. Z. Chung. 1992. Cloning, expression, and characterization of a gene encoding the human angiotensin II type 1A receptor. Biochem. Biophys. Res. Commun. 186:277-284.

11. Takayanagi, R., K. Ohnaka, Y. Sakai, R. Nakao, T. Yanase, M. Haji, T Inagami, H. Furuta, D. F. Gou, M. Nakamuta, et al. 1992. Molecular cloning, sequence analysis and expression of a cDNA encoding human type-1 angiotensin II receptor. Biochem. Biophys. Res. Commun. 183:910-916.

12. Yoshida, H., J. Kakuchi, D. F. Guo, H. Furuta, N. Iwai, R. Jong, T. Inagami, and I. Ichikawa. 1992. Analysis of the evolution of angiotensin II type 1 receptor gene in mammals (mouse, rat, bovine, and human). Biochem. Biophys. Res. Commun. 186:1042-1049.

13. Kakar, S. S., J. C. Sellers, D. C. Devor, L. C. Musgrove, and J. D. Neill 1992. Angiotensin II type-1 receptor subtype cDNAs: differential tissue expression and hormonal regulation. Biochem. Biophys. Res. Commun. 183:10901096.

14. Morgan, H. E., and K. M. Baker. 1991. Cardiac hypertrophy: mechanical, neural, and endocrine dependence. Circulation. 83:13-25.

15. Blumberg, A. L., J. A. Ackerly, and M. J. Peach. 1975. Differentiation of neurogenic and myocardial angiotensin II receptors in isolated rabbit atria. Circ. Res. 38:26-30.

16. Magrini, F. P., P. Reggiani, N. Roberts, R. Meazza, M. Ciulla, and A. Zanchetti. 1988. Effects of angiotensin and angiotensin blockade on coronary circulation and coronary reserve. Am. J. Med. 84(Suppl. 3A):55-60.

17. Grady, E. F., L. A. Sechi, C. A. Griffin, M. Schambelan, and J. E. Kalinyak. 1991. Expression of AT2 receptors in the developing rat fetus. J. Clin. Invest. 88:921-933.

18. Vinswanathan, M., K. Tsutsumi, F. M. A. Correa, and J. M. Saavedra. 1991. Changes in expression of angiotensin receptor subtypes in the rat aorta during development. Biochem. Biophys. Res. Commun. 179:1361-1367.

19. Pinson, A., P. Padieu, and I. Harary. 1987. Techniques for culturing heart cells. In The Heart Cell in Culture. Volume 1. A. Pinson, editor. CRC Press, Boca Raton, FL. 7-22.

20. Dostal, D. E., K. N. Rothblum, K. M. Conrad, G. R. Cooper, and K. M. Baker. 1992. Detection of angiotensin I and II in cultured rat cardiac myocytes and fibroblasts. Am. J. Physiol. 263:C851-C863.

21. Baker, K. M., C. P. Campanile, G. J. Trachte, and M. J. Peach. 1984 Identification and characterization of the rabbit angiotensin II myocardial receptor. Circ. Res. 286-293.

22. Schorb, W., G. W. Booz, D. E. Dostal, K. M. Conrad, K. C. Chang, and K. M. Baker. 1993. Angiotensin II is mitogenic in neonatal rat cardiac fibroblasts. Circ. Res. 72:1245-1254.

23. Meggs, L. G., J. Coupet, H. Huang, W. Cheng, P. Li, J. M. Capasso, C. J. Homcy, and P. Anversa. 1993. Regulation of angiotensin II receptors on ventricular myocytes after myocardial infarction in rats. Circ. Res. 72:1149-1162.
24. Sadoshima, J., and S. Izumo. 1993. Molecular characterization of angiotensin II-induced hypertrophy of cardiac myocytes and hyperplasia of cardiac fibroblasts: critical role of the AT1 receptor subtype. Circ. Res. 73:413-423.

25. Chen, F.-C. M., and M. P. Printz. 1983. Chronic estrogen treatment reduces angiotensin II receptors in the anterior pituitary. Endocrinology. 113:15031510.

26. Kambayashi, Y., S. Bardhan, and T. Inagami. 1993. Peptide growth factors markedly decrease the ligand binding of angiotensin II type 2 receptor in rat cultured vascular smooth muscle cells. Biochem. Biophys. Res. Commun. 194:478-482.

27. Coghlan, J. P., A. Butkus, D. A. Denton, W. F. Graham, T. J. Humphery, B. A. Scoggins, and J. A. Whitworth. 1980. Steroid receptors and hypertension. Circ. Res. 46(Suppl. I):I-88-I-93.

28. Grünfeld, J. P., and L. Eloy. 1987. Glucocorticoids modulate vascular reactivity in the rat. Hypertension. 10:608-618.

29. Rogers, T. B., S. T. Gaa, and I. S. Allen. 1986. Identification and characterization of functional angiotensin II receptors on cultured heart myocytes. $J$. Pharmacol. Exp. Ther. 236:438-444.

30. Kitami, Y., T. Okura, K. Marumoto, R. Wakamiya, and K. Hiwada. 1992. Differential gene expression and regulation of type-1 angiotensin II receptor subtypes in the rat. Biochem. Biophys. Res. Commun. 188:446-452.

31. Beverley, S. M. 1991. The polymerase chain reaction. In Current Protocol in Molecular Biology. F. M. Ausubel, R. Brent, R. E. Kingston, D. D. Moore, J. G. Seidman, J. A. Smith, and K. Struhl, editors. Greene Publishing Associates, Brooklyn, NY. 15.2.1-15.2.9.

32. Greenberg, M. E., and T. P. Bender. 1991. Identification of newly transcribed RNA. In Current Protocol in Molecular Biology. F. M. Ausubel, R. Brent, R. E. Kingston, D. D. Moore, J. G. Seidman, J. A. Smith, and K. Struhl, editors. Greene Publishing Associates, Brooklyn, NY. 4.10.1-4.10.9.

33. Mori, Y., M. Nishikawa, H. Matsubara, N. Toyoda, H. Masaki, T. Yonemoto, T. Takagi, and M. Inada. 1991. Regulation of atrial natriuretic hormone production by triiodothyronine in cultured rat atrial myocytes. Acta Endocrinol. 125:694-699.

34. Iwai, N., T. Inagami, N. Ohmichi, Y. Nakamura, Y. Saeki, and M. Kinoshita. 1992. Differential regulation of rat AT1a and AT1b receptor mRNA. Biochem. Biophys. Res. Commun. 188:298-303.

35. Johnson, M. C., and G. Aguilera. 1991. Angiotensin II receptor subtypes and coupling to signaling systems in cultured fetal fibroblasts. Endocrinology. 129:1266-1274.

36. Sakaue, M., and B. B. Hoffman. 1991. Glucocorticoids induce transcription and expression of the $\alpha 1 \mathrm{~B}$ adrenergic receptor gene in DTT1 MF-2 smooth muscle cells. J. Clin. Invest. 88:385-389.

37. Neyses, L., H. Vetter, V. P. Sukhatme, and R.S. Williams. 1989. Angiotensin II induces expression of the early growth response gene 1 in isolated adult cardiomyocytes. Circulation 80(Suppl. I):I-450. (Abstr.)

38. Jalil, J. E., J. S. Janicki, R. Pick, and K. T. Weber. 1990. Coronary vascular remodeling and myocardial fibrosis in the rat with renovascular hypertension: response to captoril. Am. J. Hypertens. 4:51-55.

39. Krimpen, V. C., J. F. M. Smits, J. P. M. Cleutjens, J. J. M. Debets, R. G. Schoemaker, H. A. J. Boudier, F. T. Bosman, and M. J. A. P. Maemen. 1991 DNA synthesis in the non-infarcted cardiac interstitium after left coronary artery ligation in the rat: effect of captoril. J. Mol. Cell. Cardiol. 23:1245-1253.

40. Urata, H., B. Healy, R. W. Stewart, F. M. Bumps, and A. Husain. 1989. Angiotensin II receptors in normal and failing human hearts. J. Clin. Endocrinol. Metab. 69:54-66.

41. Viswanathan, M., C. Strömberg, A. Seltzer, and J. M. Saavedra. 1992. Balloon angioplasty enhances the expression of angiotensin II AT1 receptors in neointima of rat aorta. J. Clin. Invest. 90:1707-1712.

42. Hausner, E. A., M. J. Turner, J. M. Trzaskos, and W. F. Herblin. 1993. Angiotensin II receptors in rabbit vascular grafts. Biochem. Biophys. Res. Commun. 190:27-32.

43. Matsubara, H., Y. Hirata, H. Yoshimi, S. Takata, Y. Takagi, Y. Umeda, Y. Yamane, and M. Inada. 1988. Role of calcium and protein kinase $\mathrm{C}$ in ANP secretion by cultured rat cardiomyocytes. Am. J. Physiol. 24:H405-H409.

44. Cantin, M., N. Dagenais, L. Salmi, J. Gutkowska, M. Ballak, G. Thibault, R. Garcia, and J. Genest. 1985. Secretory patterns of atrial natriuretic factor (ANF) by cultured cardiocytes of right and left atrium from newborn and adult rats. Clin. Exp. Hypertens. 7:685-705.

45. Ringold, G. M. 1985. Steroid hormone regulation of gene expression. Annu. Rev. Pharmacol. Toxicol. 25:529-566.

46. Palmiter, R. D., and N. H. Carey. 1974. Rapid inactivation of ovalbumin messenger ribonucletic acid after acute withdrawal of estrogen. Proc. Natl. Acad. Sci. USA. 71:2357-2361.

47. Colison, P., J. Ibarondo, G. Devilliers, M. N. Balestre, A. Duvoid, and G. Guillon. 1992. Upregulation of Vla vasopressin receptors by glucocorticoids. Am. J. Physiol. 263:E1054-E1062. 